\title{
PENGARUH PEMBELAJARAN DENGAN MODEL PROBLEM SOLVING FISIKA TERHADAP HASIL BELAJAR KOGNITIF DAN KEMAMPUAN BERPIKIR KRITIS SISWA
}

\author{
Yenni Novita Lestari*, Eko Swistoro, Andik Purwanto
}

\author{
Program Studi S1 Pendidikan Fisika Fakultas Keguruan dan Ilmu Pendidikan \\ Universitas Bengkulu \\ Jl. WR. Supratman, Kandang Limun, Bengkulu \\ e-mail*: yenninovita33@gmail.com
}

\begin{tabular}{c|c|c}
\hline Diterima 29 Juli 2019 & Disetujui 28 Agustus 2019 & Dipublikasikan 3 September 2019 \\
\hline & https://doi.org/10.33369/jkf.2.2.121-128 \\
\hline
\end{tabular}

\begin{abstract}
ABSTRAK
Penelitian ini bertujuan untuk menguji pengaruh pembelajaran dengan model Problem Solving Fisika (PSF) terhadap hasil belajar pada ranah kognitif dan kemampuan berpikir kritis. Penelitian ini menggunakan disain nonequivalent control group design untuk meneliti pengaruh model PSF terhadap hasil belajar kognitif dan one group pretest posttest design untuk meneliti pengaruh model PSF terhadap kemampuan berpikir kritis. Berdasarkan analisis data, diperoleh bahwa: (1) dengan meggunakan uji-t dua sampel independen, terdapat pengaruh yang signifikan pembelajaran dengan model PSF terhadap hasil belajar kognitif dengan nilai $t_{\text {hitung }}>t_{\text {tabel }}(2,63>2,00)$ dan effect size sebesar 0,6 (kategori sedang) dan (2) terdapat pengaruh yang signifikan pembelajaran dengan model PSF terhadap kemampuan berpikir kritis yang diketahui dengan adanya selisih antara skor rata-rata posttest dengan pretest $\left(\mathrm{O}_{2}-\mathrm{O}_{1}\right)$ sebesar 37,38 dan effect size sebesar 3,0 (kategori kuat). Kesimpulan penelitian ini adalah terdapat pengaruh yang signifikan pembelajaran menggunakan model problem solving fisika terhadap hasil belajar kognitif dan kemampuan berpikir kritis.
\end{abstract}

Kata kunci: Model Problem Solving Fisika, Hasil Belajar Kognitif, Kemampuan Berpikir Kritis

\section{ABSTRACT}

The aims of this research were to examine the effect of learning with the Problem Solving Fisika (PSF) model on learning outcomes in the cognitive domain and critical thinking abilities. This research used nonequivalent control group design to examine the effect of the PSF model on cognitive learning outcomes and one group pretest posttest design to examine the effect of the PSF model on critical thinking ability. Based on data analysis, it showed that: (1) with using the t-test two independent samples, there was a significant effect of learning with the PSF model on cognitive learning outcomes with a value that is $t_{\text {count }}>t_{\text {table }}(2,63>2.00)$, with effect size of 0.6 which is in the medium category and 2) there was a significant effect of learning with the PSF model on critical thinking abilities known by the difference between the average posttest score with an average score of pretest $\left(\mathrm{O}_{2}-\mathrm{O}_{1}\right)$ of 37.38 with effect size of 3,0, which is in the high category. The conclusion of this study shows that there is a significant effect of learning using Problem Solving Fisika model on cognitive learning outcomes and critical thinking ability.

Keywords: Problem Solving Fisika Model, Cognitive Learning Outcomes, Critical Thinking Ability

\section{PENDAHULUAN}

Fisika merupakan salah satu pelajaran yang tidak disukai oleh sebagian besar siswa SMP/SMA. Fisika dianggap sebagai pelajaran yang sulit untuk siswa dari sekolah menengah ke Universitas. Ketidaksukaan terhadap fisika ini disebabkan karena siswa mengalami kesulitan belajar sains khususnya fisika [1]. Menurut PISA (Programme for International Students Assessment) 2015, kualitas pendidikan di indonesia masih sangat rendah dan sangat mengkhawatirkan. Dalam studi PISA siswa Indonesia masih lemah dalam menjawab soal yang mengacu pada kemampuan berpikir kritis, logis dan pemecahan masalah [2].

Berpikir kritis saat ini menjadi salah satu tujuan penting dari pendidikan. Di berbagai negara, berpikir kritis telah menjadi salah satu kompetensi, tujuan dan sasaran yang ingin dicapai dalam pendidikan. Berpikir kritis merupakan kemampuan yang esensial untuk kehidupan dan berfungsi efektif dalam semua aspek kehidupan. Para pendidik telah lama menyadari pentingnya kemampuan 
berpikir kritis sebagai salah satu output dari proses pembelajaran. Dewasa ini Partnership for 21st Century Skills telah mengidentifikasi bahwa berpikir kritis menjadi salah satu dari beberapa kemampuan yang dibutuhkan untuk menyiapkan siswa pada jenjang pendidikan dan dunia kerja [3].

SMA Negeri 8 Kota Bengkulu adalah salah satu sekolah yang sudah menerapkan kurikulum 2013. Pada pembelajaran fisika saat ini, guru sudah menerapkan beberapa model pembelajaran. Namun, masih banyak siswa yang beranggapan bahwa mata pelajaran fisika sulit dipahami, menjemukan dan membosankan, sehingga tidak sedikit siswa yang mengalami kesulitan dalam memahaminya. Hal ini dapat dilihat dari hasil belajar fisika siswa dari segi kognitif masih belum optimal, Proses pembelajaran fisika saat ini berlangsung sebatas pada upaya memberikan pengetahuan deklaratif dalam menggunakan rumus-rumus menyelesaikan soal. Akibatnya kemampuan siswa dalam pembelajaran fisika hanya terbatas sampai pada kemampuan menghapalkan sekumpulan fakta yang disajikan guru dan tidak mengarah ke pemahaman konsep. Dalam proses pembelajaran di kelas siswa masih cenderung pasif. Siswa hanya menerima materi yang disampaikan dan tidak memanfaatkan kesempatan untuk bertanya, namun ketika guru yang bertanya kepada siswa, tidak ada yang mau menjawab tetapi mereka menjawab secara bersamaan sehingga suaranya tidak jelas. Rasa keingintahuan siswa dalam mencari informasi masih rendah yang merupakan indikator rendahnya kemampuan berpikir kritis.

Salah satu model pembelajaran yang dapat mengembangkan kemampuan berpikir kritis yaitu model Problem Solving Fisika (PSF) merupakan suatu cara penyajian pembelajaran untuk mendorong siswa mencari solusi dalam memecahkan masalah untuk pencapaian tujuan pembelajaran fisika. Model Problem Solving Fisika (PSF) ini adalah model pembelajaran problem solving untuk pembelajaran fisika. Pembelajaran dengan menggunakan model problem solving fisika melibatkan siswa aktif dalam memecahkan masalah dan menitikberatkan agar siswa mampu mengutarakan tujuan, menganalisa data, mengemukakan pendapat dan memberi keputusan ketika menghadapi suatu permasalahan di dalam proses pembelajaran fisika, selain itu juga membimbing siswa menjadi problem solver yang berkompeten [4].

Model pembelajaran problem solving fisika ( PSF) dilaksanakan dengan lima langkah pembelajaran, yaitu: (1) memahami masalah (2) menjabarkan masalah ke dalam aspek fisika (3) merencanakan pemecahan masalah (4) menjalankan rencana, dan (5) evaluasi dan perluasan [5]. Penelitian model PSF masih jarang dilakukan di SMA, oleh karena itu dilakukan penelitian eksperimen menggunakan model PSF pada topik momentum dan impuls di SMAN 8 Kota Bengkulu. Berdasarkan uraian tersebut dirumuskan masalah sebagai berikut: 1) Apakah terdapat pengaruh yang signifikan pembelajaran dengan model Problem Solving Fisika terhadap hasil belajar kognitif? 2) Berapa besar pengaruh model Problem Solving Fisika terhadap hasil belajar kognitif? 3) Apakah terdapat pengaruh yang signifikan pembelajaran dengan model Problem Solving Fisika terhadap kemampuan berpikir kritis? 4) Berapa besar pengaruh model Problem Solving Fisika terhadap kemampuan berpikir kritis? Tujuan penelitian ini adalah untuk menentukan pengaruh dan besar pengaruh model PSF terhadap hasil belajar kognitif dan kemampuan berpikir kritis siswa pada materi momentum dan impuls.

\section{METODE PENELITIAN}

Jenis penelitian yang digunakan adalah penelitian eksperimen (experiment research). Penelitian ini menggunakan dua desain yaitu quasi experimental design (eksperimen semu) untuk melihat pengaruh model pembelajaran Problem Solving Fisika terhadap hasil belajar kognitif siswa dan pre-experimental design untuk melihat pengaruh model pembelajaran Problem Solving Fisika terhadap kemampuan berpikir kritis siswa. Penelitian ini menggunakan dua desain karena indikator kemampuan berpikir kritis tidak diajarkan di kelas kontrol.

Penelitian ini dilaksanakan di SMA Negeri 8 Kota Bengkulu pada tanggal 25 Februari sampai dengan 22 Mei 2019 pada semester genap tahun ajaran 2018/2019. Pada penelitian ini pengambilan sampel dilakukan dengan teknik sampling purposive. Pengambilan sampel dengan teknik sampling purposive dalam penelitian ini dilakukan dengan mengambil 2 kelas dari 4 kelas X MIA yang ditentukan oleh pertimbangan guru fisika SMA Negeri 8 Kota Bengkulu. Guru mempertimbangkan

Pengaruh Pembelajaran dengan Model Problem Solving Fisika terhadap Hasil Belajar Kognitif dan Kemampuan Berpikir Kritis Siswa

Yenni Novita Lestari, Eko Swistoro, Andik Purwanto 
kelas yang diteliti berdasarkan nilai ulangan harian siswa. Kelas X MIA 1 sebagai kelas eksperimen diajarkan menggunakan model Problem Solving Fisika sedangkan kelas X MIA 2 sebagai kelas kontrol diajarkan menggunakan model Direct Instruction.

Teknik pengumpulan data dalam penelitian ini dengan melakukan 2 tes yaitu pretest dan posttest. Dengan soal pretest dan soal posttest adalah soal yang sama dan berbentuk essay. Tes hasil belajar kognitif diberikan di kelas eksperimen dan kelas kontrol, sedangkan tes kemampuan berpikir kritis diberikan di kelas eksperimen saja. Pengaruh model problem solving fisika terhadap hasil belajar kognitif dianalisis menggunakan uji t terhadap rata-rata nilai posttest kedua kelas, sedangkan pengaruh model problem solving fisika terhadap kemampuan berpikir kritis dianalisis dengan menghitung selisih posttest dan pretest $\left(\mathrm{O}_{2}-\mathrm{O}_{1}\right)$.

Dalam penelitian ini analisis parametrik yang digunakan untuk menentukan pengaruh model problem solving fisika terhadap hasil belajar kognitif adalah uji t karena data rata-rata posttest hasil belajar kognitif yang diperoleh berdistribusi normal dan homogen. Rumus t-test yang digunakan yaitu uji $\mathrm{t}$ polled varian dengan derajat kebebasan $(d k)=n_{1}+n_{2}-2$ [6], dengan persamaan sebagai berikut:

$$
\mathrm{t}=\frac{\bar{X}_{1}-\bar{X}_{2}}{\sqrt{\frac{\left(n_{1}-1\right) S_{1}^{2}+\left(n_{2}-1\right) S_{2}^{2}}{n_{1}+n_{2}-2}\left(\frac{1}{n_{1}}+\frac{1}{n_{2}}\right)}}
$$

t adalah skor t hitung dengan $\bar{X}_{1}$ adalah rata-rata data $1, \bar{X}_{2}$ adalah rata-rata data $2, \mathrm{n}_{1}$ adalah jumlah sampel kelompok $1, \mathrm{n}_{2}$ adalah jumlah sampel kelompok 2, dan $\mathrm{S}^{2}$ adalah varians dari tiap kelompok. Jika nilai $t_{\text {hitung }}>t_{\text {tabel }}$ pada taraf signifikasi $(\alpha)=0,05$, maka Ha diterima sedangkan Ho ditolak. Jika harga $t_{\text {hitung }}<t_{\text {tabel }}$ maka Ha ditolak sedangkan Ho diterima. Berdasarkan hasil analisis data tersebut dapat disimpulkan apakah hipotesis yang diajukan dalam penelitian ini diterima atau ditolak. Hipotresis $\mathrm{Ho}_{1}$ dalam penelitian ini adalah tidak ada perbedaan signifikan hasil belajar kognitif antara kelas control dan kelas eksperiman. Sedangkan hipotesis $\mathrm{Ha}_{1}$ adalah sebaliknya. Kemudian, hipotesis $\mathrm{Ho}_{2}$ adalah tidak ada perbedaan signifikan kemampuan berpikir kritis sebelum dan sesudah perlakuan. Sedangkan hipotesis $\mathrm{Ha}_{2}$ adalah sebaliknya.

Setelah diperoleh bahwa model problem solving fisika memberikan pengaruh terhadap hasil belajar kognitif, maka selanjutnya dilakukan uji effect size untuk mengetahui besar pengaruh pembelajaran dengan model Problem Solving Fisika terhadap hasil belajar kognitif. Effect size adalah ukuran mengenai besarnya pengaruh suatu variabel terhadap variabel lainnya. Effect size memberikan informasi tentang ukuran (size) dari akibat suatu perlakuan eksperimen (effect) yang sangat penting karena memberikan ukuran seberapa besar pengaruh perlakuan terhadap suatu variabel dalam eksperimen [7]. Perhitungan effect size untuk mengukur besar pengaruh model Problem Solving Fisika terhadap hasil belajar kognitif dilakukan dengan menggunakan rumus Cohen's d.

$$
d=\frac{\overline{x_{E}}-\overline{x_{C}}}{S_{\text {pooled }}}
$$

dimana,

$$
S_{\text {pooled }}=\sqrt{\frac{\left(n_{E}-1\right) \mathrm{S}_{E}^{2}+\left(\mathrm{n}_{C}-1\right) \mathrm{S}_{C}^{2}}{n_{E}+n_{C}-2}}
$$

$\mathrm{d}$ adalah effect size, $\overline{x_{E}}$ adalah rata-rata posttest kelas eksperimen, $\overline{x_{C}}$ adalah rata-rata posttest kelas kontrol, $\mathrm{S}_{E}^{2}$ adalah varians kelas eksperimen, $\mathrm{S}_{C}^{2}$ adalah varians kelas kontrol, $\mathrm{S}_{\text {pooled }}$ adalah standar deviasi gabungan, $\mathrm{n}_{\mathrm{E}}$ adalah jumlah siswa kelas eksperimen, $\mathrm{n}_{\mathrm{C}}$ adalah jumlah siswa kelas kontrol. 
Perhitungan besar pengaruh atau effect size pembelajaran dengan model Problem Solving Fisika terhadap kemampuan berpikir kritis dilakukan dengan menggunakan rumus yang berbeda, karena disain penelitian yang digunakan adalah One Grup Pretest-Posttest Group Design. Untuk mengetahui besar pengaruh setelah diberikan perlakuan dibutuhkan skor rata-rata sebelum diberikan perlakuan $\left(\bar{x}_{\text {pre }}\right)$ dan skor rata-rata setelah diberi perlakuan $\left(\bar{x}_{\text {post }}\right)$, serta standar deviasi sebelum diberi perlakuan $\left({ }^{s_{p r e}}\right)$ dan standar deviasi setelah diberi perlakuan $\left({ }^{s_{\text {post }}}\right)$ [8]. Sehingga persamaan effect zise dirumuskan sebagai berikut:

$$
d=\frac{\left(\bar{x}_{\text {post }}\right)-\left(\bar{x}_{\text {pre }}\right)}{S_{\text {pooled }}}
$$

dimana,

$$
S_{\text {pooled }}=\sqrt{\frac{\mathrm{S}_{\text {pre }}{ }^{2}+S_{\text {post }}{ }^{2}}{2}}
$$

Hasil perhitungan effect size diinterpretasikan dengan menggunakan klasifikasi Cohen. [9]

\section{HASIL DAN PEMBAHASAN}

\subsection{Pengaruh Model Problem Solving Fisika Terhadap Hasil Belajar Kognitif Siswa Kelas} Eksperimen dan Kelas Kontrol

Berdasarkan hasil penelitian kelas eksperimen memperoleh nilai rata-rata pretest sebesar 27,73 dan rata rata posttest sebesar 78,48. Untuk kelas kontrol memperoleh nilai rata-rata pretest sebesar 27,40 dan rata-rata posttest sebesar 73,58. Skor rata-rata pretest dan posttest kelas eksperimen lebih tinggi dibandingkan kelas kontrol. Skor rata-rata pretest dan posttest kelas kontrol dengan model Direct Instruction juga sudah tinggi dan selisih dengan skor rata-rata posttest kelas eksperimen tidak terlalu jahu, hal ini dikarenakan model Direct Instruction memiliki kelebihan yakni guru lebih dapat mengendalikan isi materi dan urutan informasi yang diterima oleh siswa, hanya saja belum mencapai KKM sekolah yang diharapkan. Untuk lebih jelas hasil rata-rata pretest dan posttest hasil belajar kognitif ditunjukkan oleh gambar 1.

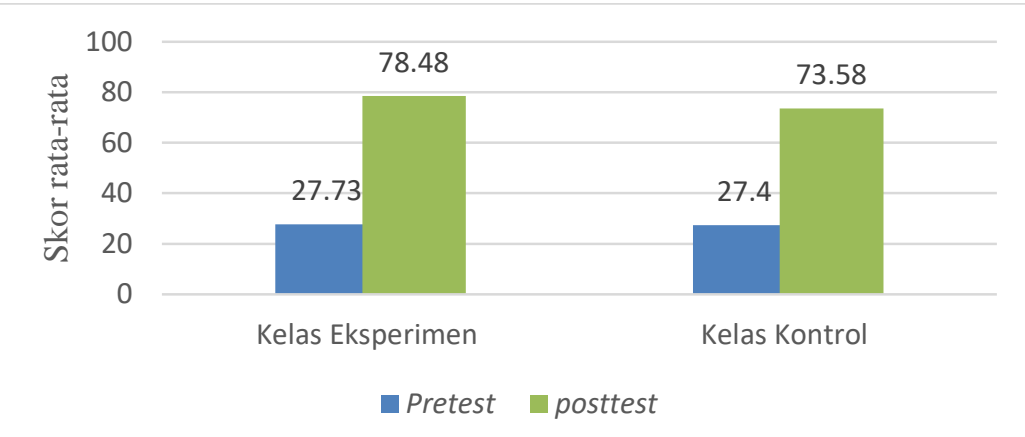

Gambar 1. Rata-rata hasil tes hasil belajar kognitif pretest dan posttest kelas eksperimen dan kelas kontrol

Untuk mengetahui data hasil penelitian berdistribusi normal atau tidak. Maka dilakukan uji normalitas nilai rata-rata pretest dan posttest hasil belajar kognitif. Hasil dari uji normalitas dapat dilihat dalam tabel 1 .

Tabel 1. Hasil Perhitungan Uji Normalitas Hasil Belajar kognitif

\begin{tabular}{ccccc}
\hline Kelas & Data & $\mathbf{X}^{2}$ hitung & $\mathbf{X}^{2}$ tabel & Distribusi Data $(\boldsymbol{\alpha}=5 \%, \mathrm{dk}=5)$ \\
\hline \multirow{2}{*}{ Eksperimen } & Pretest & 5,12 & 11,07 & Normal \\
\cline { 2 - 5 } & Posttest & 8,46 & 11,07 & Normal \\
\hline \multirow{2}{*}{ Kontrol } & Pretest & 3,19 & 11,07 & Normal \\
\cline { 2 - 5 } & Posttest & 7,42 & 11,07 & Normal \\
\hline
\end{tabular}


Selanjutnya untuk menentukan apakah sampel berasal dari varians yang homogen, dilakukan uji homogenitas nilai rata-rata pretest dan posttest hasil belajar kognitif. Hasil dari uji homogenitas dapat dilihat dalam tabel 2.

Tabel 2. Hasil Perhitungan Uji Homogenitas Hasil Belajar Kognitif

\begin{tabular}{|c|c|c|c|}
\hline \multirow{2}{*}{ Kelas } & \multirow{2}{*}{$\mathbf{N}$} & \multicolumn{2}{|c|}{ Varians } \\
\hline & & Pretest & Posttest \\
\hline Eksperimen & 33 & 61,25 & 61,17 \\
\hline Kontrol & 34 & 76,46 & 54,4 \\
\hline \multicolumn{2}{|c|}{$\mathrm{F}_{\text {hitung }}$} & 1,25 & 1,12 \\
\hline \multicolumn{2}{|c|}{$\mathrm{F}_{\text {tabel }}(\alpha=5 \%)$} & 1,79 & 1,79 \\
\hline \multicolumn{2}{|c|}{ Syarat } & $F_{\text {hitung }}<F_{\text {tabel }}$ & $F_{\text {hitung }}<F_{\text {tabel }}$ \\
\hline
\end{tabular}

Setelah didapatkan bahwa data berdistribusi normal dan homogen, maka dilakukan uji t. Berikut adalah hasil uji t nilai posttest dan pretest hasil belajar kognitif masing-masing kelas.

Tabel 3. Hasil Uji-T Hasil Belajar Kognitif

\begin{tabular}{|c|c|c|c|c|c|c|c|}
\hline Hasil & Kelas & $\mathbf{N}$ & $\begin{array}{c}\text { Rata- } \\
\text { rata }\end{array}$ & Varian & $t_{\text {hitung }}$ & $\begin{array}{c}t_{\text {tabel }} \\
(\mathbf{d k}=\mathbf{6 5}) \\
\text { tk } 5 \%\end{array}$ & Kesimpulan \\
\hline \multirow[t]{2}{*}{ Pretest } & Eksperimen & 33 & 27,73 & 61,25 & \multirow{2}{*}{0,16} & \multirow{2}{*}{2,00} & \multirow{2}{*}{$\begin{array}{c}\text { Tidak berbeda } \\
\text { signifikan }\end{array}$} \\
\hline & Kontrol & 34 & 27,40 & 76,46 & & & \\
\hline \multirow[t]{2}{*}{ Posttest } & Eksperimen & 33 & 78,48 & 61,17 & \multirow{2}{*}{2,63} & \multirow{2}{*}{2,00} & Berbeda \\
\hline & Kontrol & 34 & 73,58 & 54,39 & & & Signifikan \\
\hline
\end{tabular}

Berdasarkan tabel 3 terlihat bahwa hasil uji beda rata-rata pretest kelas eksperimen dan kelas kontrol tidak berbeda secara signifikan. Hal ini menunjukkan bahwa hasil belajar sebelum diberi perlakuan (pretest) tidak terdapat perbedaan sehingga dapat disimpulkan bahwa kedua kelas mempunyai kemampuan yang sama saat sebelum diberi perlakuan atau pretest kedua kelas tidak terdapat perbedaan yang signifikan. Berdasarkan hasil belajar sebelum diberi perlakuan (pretest) bahwa tidak terdapat perbedaan yang signifikan maka perlakuan pembelajaran dapat diberikan pada masing-masing kelas. Hasil uji t data posttest menunjukkan bahwa siswa yang diberi pembelajaran menggunakan model problem solving fisika pada kelas eksperimen memiliki nilai yang berbeda dengan nilai siswa yang menggunakan model pembelajaran direct instruction.

Perbedaan hasil belajar antara kelas eksperimen dan kelas kontrol dapat terjadi karena disebabkan oleh beberapa faktor. Salah satu faktor yang mempengaruhi hasil belajar siswa yaitu penggunaan model pembelajaran sehingga ketepatan memilih model pembelajaran diharapkan dapat meningkatkan hasil belajar siswa, terutama meningkatkan hasil belajar kognitif siswa. Salah satu alternatif model pembelajaran inovatif yang dikembangkan berlandaskan paradigma konstruktivistik yang dapat membantu siswa dalam membangun pengetahuannya yaitu model pembelajaran Problem Solving Fisika [1].

Selanjutnya untuk mengukur seberapa besar pengaruh (effect size) yang diberikan oleh pembelajaran dengan menggunakan model problem solving fisika terhadap hasil belajar kognitif, perlu dilakukan uji lanjut menggunakan rumus Cohen's. Hasil perhitungan yang diperoleh menunjukkan bahwa pengaruh yang diberikan oleh pembelajaran menggunakan model problem solving fisika berada dalam kategori sedang, yaitu sebesar 0,6. Artinya model problem solving fisika memberikan pengaruh sebesar 61,8 \% terhadap hasil belajar kognitif, dan 38,2 \% lainnya dipengaruhi oleh faktor lain.

Hasil ini sejalan dengan hasil penelitian yang diperoleh Sijabat, Motlan dan Derlina (2016) berdasarkan hasil penelitiannya didapatkan bahwa ada perbedaan hasil belajar yang menggunakan model pembelajaran problem solving dan model konvensional, yaitu siswa yang belajar dengan 
model problem solving memiliki hasil belajar yang lebih baik [10]. Hasil penelitian Warimun (2018) juga menunjukkan adanya pengaruh pembelajaran dengan model problem solving fisika terhadap pemahaman konsep yang merupakan indikator hasil belajar untuk materi termodinamika setelah diajarkan dengan menggunakan model pembelajaran problem solving fisika [5]. Selanjutnya Alim (2019) berdasarkan hasil penelitiannya, nilai rata- rata hasil belajar siswa yang diajar dengan model pembelajaran Problem solving berbantuan LKS pada materi pokok momentum dan impuls kelas X sebesar 76,28, sedangkan nilai rata-rata hasil belajar siswa yang diajar dengan model pembelajaran langsung pada materi pokok momentum dan impuls kelas X sebesar 72,84 [11]. Hal ini juga sejalan dengan penelitian Veronica, Swistoro, dan Hamdani (2018) yang menyatakan bahwa terdapat pengaruh pembelajaran menggunakan model PSF terhadap hasil belajar kognitif sebesar 0,72 yang berada pada kategori sedang [12].

Model problem solving fisika (PSF) dapat meningkatkan hasil belajar kognitif siswa karena pembelajaran problem solving fisika memberikan siswa kesempatan untuk melakukan kegiatan, merasa nyaman saat melakukan pembelajaran, aktif bertanya, dan aktif meningkatkan hasil belajar. Melalui pembelajaran dengan menggunakan model Problem Solving Fisika siswa dilatih untuk memahami masalah yang diberikan, kemudian menuliskan kembali masalah tersebut baik secara kualitatif maupun secara fisika, merencanakan langkah pemecahan, dan kemudian menjalankan rencana. Siswa kelas eksperimen telah diajarkan untuk selalu memahami dulu soal tes yang diberikan, sebelum menyelesaikannya langsung dengan persamaan matematis.

\subsection{Pengaruh Model Problem Solving Fisika Terhadap Kemampuan Berpikir Kritis}

Kemampuan berpikir kritis dalam penelitian ini dilakukan di kelas eksperimen. Data kemampuan berpikir kritis dalam penelitian ini didapat dari hasil pretest dan posttest siswa di kelas eksperimen yang diajarkan menggunakan model problem solving fisika. Hasil tes kemampuan berpikir kritis dianalisis secara terpisah dengan soal tes hasil belajar kognitif. Skor maksimum tes kemampuan berpikir kritis adalah 3 dan skor minimum adalah 0. Skor ini kemudian di konversi menjadi nilai dalam rentang 1-100. Untuk melihat pengaruh model problem solving fisika terhadap kemampuan berpikir kritis, maka dilakukan pengurangan nilai rata-rata posttest dikurangi nilai ratarata pretest. Data hasil tes kemampuan berpikir kritis ditunjukkan dalam tabel 4.

Tabel 4. Data Hasil Skor Rata-Rata Pretest dan Posttest Kemampuan Berpikir Kritis

\begin{tabular}{lcccccccc}
\hline & \multicolumn{2}{c}{ Pertemuan 1 } & \multicolumn{2}{c}{ Pertemuan 2 } & \multicolumn{2}{c}{ Pertemuan 3 } & \multicolumn{2}{c}{ Ketiga Pertemuan } \\
\cline { 2 - 9 } THBK & Mean & SD & Mean & SD & Mean & SD & Mean & SD \\
\hline Pretest & 27,27 & 15,98 & 29,63 & 12,63 & 40,07 & 13,87 & 32,32 & 12,29 \\
\hline Posttest & 63,64 & 16,02 & 67,34 & 17,11 & 78,11 & 14,3 & 69,7 & 13,30 \\
\hline
\end{tabular}

Berdasarkan hasil yang diperoleh, adanya peningkatan kemampuan berpikir kritis siswa yang diajarkan dengan model problem solving fisika. Hal ini ditunjukkan dari perbedaan antara skor ratarata pretest dan skor rata-rata posttest yang diperoleh siswa cukup jauh. Berdasarkan hasil perhitungan, selisih antara rata-rata pretest dan posttest adalah sebesar 37,38. Karena terdapat selisih dari hasil perhitungan tersebut, maka dapat disimpulkan bahwa pembelajaran dengan model problem solving fisika memberikan pengaruh terhadap kemampuan berpikir kritis siswa pada kelas eksperimen.

Selanjutnya untuk mengukur seberapa besar pengaruh (effect size) yang diberikan oleh pembelajaran dengan menggunakan model problem solving fisika terhadap kemampuan berpikir kritis, perlu dilakukan uji lanjut menggunakan rumus Cohen's. Hasil perhitungan yang diperoleh sebesar 3,0 menunjukkan bahwa pengaruh yang diberikan oleh pembelajaran menggunakan model problem solving fisika berada dalam kategori kuat. Artinya model problem solving fisika memberikan pengaruh sebesar 93,3\% terhadap kemampuan berpikir kritis.

Hasil yang didapat dalam penelitian ini sejalan dengan penelitian yang dilakukan oleh Warimun \& Murwaningsih (2013) yang menyatakan bahwa pembelajaran dengan menggunakan model problem solving dapat meningkatkan kemampuan memecahkan masalah dan kemampuan berpikir tingkat tinggi (kemampuan berpikir kritis dan kreatif). Respon siswa terhadap proses pembelajaran dengan model problem solving menunjukkan $75 \%$ suka dan mampu mengikuti pembelajaran, dan sisanya $25 \%$ siswa kurang suka dan tidak mampu mengikuti proses pembelajaran

Pengaruh Pembelajaran dengan Model Problem Solving Fisika terhadap Hasil Belajar Kognitif dan Kemampuan Berpikir Kritis Siswa

Yenni Novita Lestari, Eko Swistoro, Andik Purwanto 
[13]. Pembelajaran pada kelas eksperimen yang menggunakan model problem solving fisika mengajarkan siswa untuk bisa bekerja sama dan berdiskusi bersama temannya dalam kelompok. Siswa kelas eksperimen belajar melalui kelompok sehingga mereka bisa saling berbagai informasi dan pengetahuan, mereka saling bekerja sama dalam menyelesaikan permasalahan yang ada di LKPD. Siswa yang mengerti membantu siswa yang belum mengerti. Oleh sebab itu, kelompok harus dibagi secara merata. Melalui model problem solving fisika, siswa diajarkan untuk selalu memahami soal yang diberikan, dan diajarkan cara menuliskan besaran dan satuan fisika secara tepat.

\section{SIMPULAN DAN SARAN}

\subsection{Kesimpulan}

Berdasarkan hasil analisis data dan pembahasan yang telah dilakukan dapat disimpulkan bahwa (1) terdapat pengaruh yang signifikan pembelajaran dengan model problem solving fisika terhadap hasil belajar kognitif pada konsep momentum dan impuls ( $\left.t_{\text {hitung }}=2,63>t_{\text {tabel }}=2,00\right)$, (2) besar pengaruh (effect size) model Problem Solving Fisika terhadap hasil belajar kognitif sebesar 0,6 (kategori sedang) artinya model problem solving fisika memberikan pengaruh sebesar 61,8\% terhadap hasil belajar kognitif dan 38,2 \% lainnya dipengaruhi oleh faktor lain, (3) terdapat pengaruh yang signifikan penggunaan model pembelajaran Problem Solving Fisika terhadap kemampuan berpikir kritis siswa pada konsep momentum dan impuls dengan selisih skor rata-rata posttest dengan pretest $\left(\mathrm{O}_{2}-\mathrm{O}_{1}\right)$ sebesar 37,38; (4) besar pengaruh model Problem Solving Fisika terhadap kemampuan berpikir kritis sebesar 3,0 (kategori kuat) artinya model problem solving fisika memberikan pengaruh kuat sebesar 93,3\%.

\subsection{Saran}

Berdasarkan penelitian yang sudah dilakukan, disarankan beberapa hal, yakni (1) mengingat kelemahan model Problem Solving Fisika ini yaitu memerlukan banyak waktu, maka guru harus dapat mengatur alokasi waktu dengan sebaik-baiknya pada saat pembelajaran berlangsung agar pembelajaran dengan model Problem Solving Fisika bisa dilakukan dengan efektif; (2) bagi peneliti lanjutan, perlu dilakukan penelitian sejenis dengan menerapkan model Problem Solving Fisika untuk materi pembelajaran yang lain. Sehingga dapat diketahui sejauh mana pengaruh penggunaan model pembelajaran Problem Solving Fisika, (3) Sebelum diterapkan pembelajaran dengan model Problem Solving Fisika guru dapat memilih materi pembelajaran yang bisa dilakukan dengan menggunakan metode eksperimen sehingga siswa benar-benar melihat gejala alam yang terjadi dan dari eksperimen tersebut siswa dapat mengembangkan pemahaman konsep mereka.

\section{DAFTAR PUSTAKA}

[1] Warimun, E. S., 2012, Pengembangan Kemampuan Problem Solving Melalui Pembelajaran Topik Optika Fisis Bagi Mahasiswa Calon Guru Fisika, Prosiding Semirata BKS-PTN MIPA, 389-393, Medan, 11-12 Mei.

[2] Irawan, T. A., Rahardjo, S. B., dan Sarwanto, 2017, Analisis Kemampuan Berpikir Kritis Siswa Kelas VII-A SMP Negeri 1 Jaten, Prosiding Seminar Nasional Pendidikan Sains (SNPS), 232236, Surakarta, 26 Oktober.

[3] Zubaidah, S., Corebima, A., dan Mistianah, 2015, Asesmen Berpikir Kritis Terintegrasi Tes Essay, Symposium on Biology Education, 200-213, Yogyakarta.

[4] Warimun, E. S. , 2010, Pengembangan Kemampuan Problem Solving melalui Pembelajaran Topik Optika Bagi Mahasiswa Calon Guru Fisika, Disertasi, Bandung: Tidak diterbitkan.

[5] Warimun, E. S., 2018, Pengaruh Pembelajaran dengan Model Problem Solving Fisika terhadap Pemahaman Konsep dan Kemampuan Problem Solving pada Mahasiswa Pendidikan Fisika, Prosiding Seminar Nasional EduFisika, Jakarta, 3 Maret.

[6] Sugiyono, 2010, Metode Penelitian Pendidikan, Alfabeta, Bandung.

[7] Thalheimer, W. dan Cook, S., 2002, How to calculate effect sizes from published research: A Simplified Methodology. Diakses dari www.work-learning.com. 
[8] Kadel, R. P. dan Kip, K. E., 2015, A SAS Macro to Compute Effect Size (Cohen's) and its Confidence Interval from Raw Survey Data. SESUG, (October 2012), 1-12.

[9] Cohen, J., 1988, Statistical Power Analysis For The Behavioral Sciences, Lawrence Erlbaum Associates, New York.

[10] Sijabat, A., Motlan, dan Derlina, 2016, Pengaruh Model Pembelajaran Model Problem Solving Dan Pemahaman Konsep Terhadap Hasil Belajar Fisika Siswa. Jurnal Pendidikan Fisika Unimed, 87-91.

[11] Alim, 2019, Pengaruh Model Pembelajaran Problem Solving Berbantuan LKS terhadap Hasil Belajar Siswa pada Materi Pokok Momentum dan Impuls Kelas X Semester II di SMA Negeri 4 Tebing Tinggi T.P. 2016/2017, Jurnal Penelitian Fisikawan, No. 1, Vol. 2, 35-41.

[12] Veronica, T., Swistoro, E., dan Hamdani, D., 2018, Pengaruh Pembelajaran dengan Model Problem Solving Fisika terhadap Hasil Belajar dan Kemampuan Pemecahan Masalah Fisika Siswa Kelas XI IPA SMAN 1 Lebong, Jurnal Kumparan Fisika, No. 2, Vol. 1, 31-39

[13] Warimun, E. S. dan Murwaningsih, A., 2013, Model Pembelajaran Problem Solving Untuk Meningkatkan Pemahaman Konsep dan Keterampilan Berpikir Kritis Siswa Sekolah Menengah Atas. Jurnal Pendidikan Matematika dan Sains, No. 1, Vol. 11, $26-28$. 